\title{
THE ROLE OF FAIR VALUE MEASUREMENT IN THE RECENT FINANCIAL CRUNCH
}

\author{
David Procházka*
}

\begin{abstract}
:
Fair value measurement became pervasive to financial reporting over last 20 years. Under fair value accounting, entities are obliged or permitted to measure particular assets and liabilities at their fair values as at the reporting dates. Fair value is a current market-based hypothetical value. This market value is not always directly observable. The debate on usefulness of fair value accounting has arisen in connection with the financial crunch and economic crisis in years 2007-2009. The opponents of fair value accounting insist on that financial reporting based on fair value measurement has accelerated the financial crisis and significantly worsened the impact on affected companies. On the other hand, there are several important opinions in favour of fair value accounting. The paper aim is to contribute to the actual debate whether fair value accounting played the role of a messenger or a mover in the recent financial crunch and subsequent economic recession and to analyse the characteristics of fair value accounting from the economic point of view.
\end{abstract}

Keywords: measurement; fair value; economic income; accounting income.

JEL Classification: M41

\section{Introduction}

Measurement of accounting elements is one of the crucial factors in the process of preparing financial statements, which fairly present economic activity of an accounting entity. Elements of financial statements can be measured by various attributes, corresponding to the nature of an element and the purpose for which the element has been incurred by entity. The reliability and relevance of the attribute measured are the key points of measuring assets, liabilities, equity and other elements.

In connection with the recent financial and subsequent economic crisis, many opinions appeared blaming fair value measurements in financial statements to be one or even the main driver of the crisis. There are of course dissenting points of view. The aim of this paper is to analyse economic backgrounds of fair value and to

* David Procházka, Department of Financial Accounting and Auditing, University of Economics, Prague (prochazd@vse.cz). The paper was processed as an output of a research project Analysis of Accounting Standards for Income Reporting - New Approaches in the World and the Possibilities of Their Utilisation in the Czech Republic" (registration number GA402/09/P523). This paper won the 2nd prize in the PAPER' 10 contest announced by the Czech University of Economics in Prague. 
depict strengths and weaknesses of the fair value concept for accounting purposes. Based on these findings, the paper will evaluate the role of fair value accounting in the contemporary financial and economic crisis.

\section{Background and Literature Overview}

The conventional accounting system favours the usage of amounts at which the elements of financial statements were measured at the date of their initial recognition. Historical costs possess some advantages; objectivity and conclusive evidence are in the first place. They can serve as a prudence measure for the protection of entity's creditors. Unfortunately, historical costs are not suitable and relevant for economic decision-making and they deteriorate the stewardship function of accounting from the view of entity's owners. As a reaction to those disadvantages standard setters prefer measurement attributes based on current market information and assumptions for preparing the financial statements by publicly responsible entities. Fair value is considered the most useful market characteristics as far as measurement in financial reporting concerns. The economic background for this assertion can be found in Beatty et al. (1996), or Heaton et al. (2009). However, we should have in our mind that "fair value is not panacea and other measurement bases also have desirable characteristics" (Barth, 2006). Fair value was chosen as a preferred solution in a never-ending trade-off between reliability and relevance of accounting information.

Nobes (2001) carried out the first major analysis of fair value accounting. Plantin et al. (2005) and Penman (2006) describe plusses and minuses of contemporary fair value accounting more deeply. On the conceptual level (followed by regulatory bodies such as IASB and FASB), fair value accounting is supposed to generate information with a higher degree of decision usefulness and information-relevance of accounting data and thus provide information that is more useful to investors. As a result, investors obtain a more valuable view of an entity's well-being. Fair value eliminates the incentives to purpose-built gain trading and assets securitisation and thus increases the credibility of financial reporting. Contrariwise, if fair value cannot be determined unambiguously, fair value measurement loses its objectivity. If quoted market prices in active markets are missing, fair value can be measured only based on subjective assumptions, and thus, may become a black-box tool for discretionary earnings management and manipulation (Ryan, 2008).

Therefore, opponents of fair value accounting (further also "FVA") believe that financial reporting based on fair value measurement has accelerated the financial crisis and significantly worsened the impact on affected companies. Fair value accounting is facing to the criticism especially from the banking sector; e.g. according to the President of the American Bankers Association (2008): "The problems that exist in today's financial markets can be traced to many different factors. One key factor that is recognized as having exacerbated these problems is fair value accounting." No wonder, that the representatives of the companies strongly hit by the crunch pronounce chief objections to FVA. E.g. Martin Sullivan, AIG chief executive, said that "fair value accounting had had unintended consequences and called for its suspension" (Financial Times, 2008a). 
The strongest opposition against fair value accounting probably comes from Wallison (2008) who argues that fair value accounting has been the principal cause of an unprecedented decline in asset values; an unprecedented rise in instability among financial institutions; and the worst economic crisis in the United States since the Great Depression (Khan, 2010). Moreover, Wallison (2009, pp. 2-3) believes that fair value accounting is highly pro-cycling and should be abandoned or at least significantly modified in order to ensure that financial statements report information on stability of the entity rather than on its earnings power. The same remark on pro-cycling feature of fair value accounting and the necessity to change the mark-to-market accounting based on fair value (for the financial institutions) was expressed by Bloomfield et al. (2006) or by King (O'Grady, 2008). Last, but not at least the Chairman of Federal Reserve Bank Ben Bernanke said that "the need to mark assets at "fire sale" prices had created a vicious circle" (Rappeport, 2008). It is believed that FVA spreads this resurgent contagion among banks (Magnan, 2009) and thus can potentially lead to a breakdown of the entire banking system (Khan, 2010) with possible impact to real economy.

There are some supporting views also from academics, e.g. Abdel-Khalik (2008) criticises fair value measurement from the point of inconsistency of measurement within financial statements. According to his opinion, the mixture of measurement bases used hinder the users from making judgement on what happened with their money (i.e. stewardship function of accounting) and what management will be able to do with their money (i.e. function of accounting as a source of information for decision-making). However, Abdel-Khalik does not call for abandoning the fair value measurement; he adheres to separate sets of financial statements each using a single measurement basis.

On the other hand, there are several important opinions in favour of FVA. Rummell (2008) pointed out, that critics had confused the cause and the consequence by stating that "banks mounting loan losses are leading to a growing number of calls to shoot the messenger-fair-value accounting standards". The supporters of FVA claims that financial reporting based on FV is just a messenger, which transmit information on what has actually happened (Financial Times, 2008b). Veron (2008) and Andre et al. (2009) carry out a deeper analysis of the role of FVA in the current crisis and the effort to "shoot the messenger". Escaffre et al. (2008) argues against virulent attacks on fair value accounting due to its (alleged) pro-cyclicality.

Because of recent development in standard-setting process, fair value measurement has become pervasive to financial reporting and has resulted in unprecedented shift in the content, significance and usefulness of information about financial position and performance. The accounting perception of economic phenomena and the way how to present the economic course of an entity's life in financial statements is altering so enormously that some authors, e.g. Barlev (2003) or Hitz (2006), talk about change in accounting paradigm with reference to Kuhn's (1962) "theory of paradigm shift".

In connection with the recent financial crunch, several new issues regarding fair value occurred. The unrealised gains and losses from changes in the fair value imply that dividends may well be paid in advance of any cash flow is obtained. ${ }^{1}$ Moreover, the

1 See the statement of Australian Accounting Research Foundation (1997, p. 65) in the case of agriculture. 
subjectivity in estimates of fair value opens space for manipulation with the earnings (Herbohn, 2006 and Ryan, 2008). Fair values can be unreliable because of intrinsic error in the measurement or the input to the measurement. Fair value measurements may be derived from models that contain simplified assumptions that introduce measurement error and require inputs (such as income or cash flow forecasts) that are themselves subject to measurement error. Thus, the functions of accounting can be violated.

As the literature overview shows, there is a huge amount of literature relating to both general measurement issues and the impact of fair value on economy during the recent crunch, too. Some authors have scrutinised the influence of fair value measurement on the companies using empirical data from their financial statement to evaluate the extent of FVA and their possible effect on deepening the financial and economic crisis. Other authors have searched for arguments based on accounting theory, which can help depict strengths and weaknesses of FVA in general and in unstable times specifically. Both approaches are of a great value and provide us with important insight into the nature and causes of the slump and the role of FVA.

Nevertheless, an important aspect is on the edge of interest in the current debate. Accounting is a tool of transmitting the economic information about subjects operating in economic environment. Therefore, the verdicts on the role of FVA during the crisis ought to be backed up by the corresponding inferences of economic theory. Therefore, selected economic theories (Chapter 3) will be employed during the discussion (Chapter 4). The paper's conclusions should serve as a contribution to the actual debate whether current guidance on fair value accounting played the role of a messenger or a cause in the recent financial crunch and subsequent economic crisis. As a starting point for this evaluation, main concerns about fair value measurement are summarised in brief:

- Unrealised profits - revaluation of assets and liabilities at the balance date to their up-to-date fair value can lead to recognition of unrealised gains. If the unrealised profit is distributed to the owners, the entity's capital can be eroded. The risk of inappropriate distribution of unrealised profits is in a question esp. under situation of bubble price development.

- Reliability of measurement - fair value is a hypothetical value reflecting fair conditions and positions of all market participants. In many cases, an estimate of such conditions has to be made in order to derive to fair value. The reliability of fair value measurement is impeded esp. in inactive and illiquid markets and under mass sale out of a particular asset. As consequence, failure is reported as a success and vice versa.

- Relevance of measurement - there are some doubts about relevance of information contained in income statement and the usefulness of net income as a measure of management performance when mixed bases measure balance sheet elements.

- Suboptimal behaviour - mark-to-market and fair value accounting leads to premature recognition of profits in comparison with traditional historical cost model. Management may be impelled to adverse selections in order to meet expected or targeted numbers. This is mainly the case of financial instruments. Some bodies believe that suboptimal behaviour of companies may influence the markets and may cause systematic market risk and pro-cyclicality on the aggregate level. On the company's level, fair value accounting leads to increase in information asymmetry and reducing transparency of financial statements. 


\section{The Economic Features of Market Price and Fair Value}

\subsection{Economic and accounting concept of income}

The mutual relation between capital and income was firstly scrutinised by the economist Irving Fisher (1906 and 1930) who asserted that value of capital is equal to discounted (capitalised) value of future incomes. Interest rate fulfils a function of the bridge connecting income and capital. Modern economic theories define income (profit) in terms of capitalised value of a company net assets (or capital). If the value of capital at the end of the period is higher than it was at the beginning of the period, entity has experienced profit. Economic profit represents the increase in wealth of an entity.

Accounting theory tries to offer an income concept, which respects economic characteristics of business on the one hand and which is operational in practice on the other hand. The first major attempts in this field were introduced by Edwards and Bell (in year 1961) and Chambers (in year 1966). Chambers (1974, pp. 220-227) operates with current cash equivalents in his income theory. Chambers calls for the use of one single measurement attribute. For the reason of evaluating the entity's ability to engage in relations with other market participants, Chambers favours current cash equivalents, i.e. realisable price. We can extend his theory to whichever measurement basis and thus derive a general definition of accounting income.

$$
\text { Profit }=E_{(t)}^{M B}-E_{(t-1)}^{M B}
$$

where $E_{(t)}$ - equity (net assets) in moment $\mathrm{t}$,

$E_{(t-1)}-$ equity (net assets) in moment t-1,

$M B$ - chosen measurement basis.

For practical purposes, it is convenient to separate profit into the realised and unrealised part. We can utilise concept of income worked out by Edwards and Bell (1973) who introduced opportunity costs for determination of expected realisable profit. Regardless which theory we choose as the guiding concept, the common feature of all theories is obvious. The authors plead for a uniform usage of one single basis for the purposes of accounting measurement. These claims together with the capital maintenance approach applied have substantial consequences for many accounting figures and for the usefulness of accounting information on financial position and performance. When respecting this requirement, we are able to calculate the accounting income, which features are similar to the economic income. Economic profit expresses the fact that entity has succeeded in retaining its earnings potential. In economics, the maintenance of capital is an inevitable consequence of income definition. In accounting, the capital maintenance is a starting point for all consideration about income determination. 


\subsection{Fair value and its economic features}

Traditionally, income based on money capital maintenance was used in financial reporting. Conventional historical cost model serves as an initial foundation for evaluation of stewardship. The introduction of fair value changed the perception and content of traditional accounting income. Despite the fact that fair value has not been mentioned by any of the famous accounting theoreticians, it could serve as a single basis for measurement of all accounting elements - at least on the theoretical level.

Richard (2002) showed that a special kind of fair value valuation was introduced by the German and French legislation in $19^{\text {th }}$ century with the impact on accounting practice until the beginning of the $20^{\text {th }}$ century. The birth of fair value concept in accounting theory can be traced back to the 30's of the $20^{\text {th }}$ century, e.g. MacNeal's work from 1939, in which he preferred measurement of all accounting elements by the economic value.

MacNeal inclines to the economic concept of income, which he defines as a surplus of capital value at the end of the period after the capital was maintained or costs were recovered. As MacNeal prefers the using of market values for measurement of balance sheet elements and calls for the inclusion of all changes (even unrealised) in the value of assets and liabilities in the profit and loss, its approach to income determination corresponds to the physical capital maintenance concept. However, he does not specify if the market value applied is the entry or exit price. He calls the measurement basis as the economic value. "The economic value of anything is its "power in exchange", which, measured in money, is its market price" (MacNeal, 1979, p. 87). Current market price is an intersection of activity of many economic subjects and their preferences.

As fair value is a hypothetical market price, the starting point for all fair value measurement considerations is the market place. The market is a result of human action, but not human design (Hayek, 1967) that conveys information in the form of prices. Market price embodies the consensus view of all marketplace participants on goods traded. From the economic point of view, market price is an intersection of marketplace participants' views of goods utility, future cash flows from the goods and the uncertainties surrounding those cash flows. Moreover, the market is the only arbiter of values. Some participants may apprehend the market price as over- or undervalued. However, only the future arrangement of market prices can vindicate if their action to make profit due to previous alleged "non-equilibrium" price was successful.

There are monetary units and there are measurable physical units of various economic goods. The mutual exchange ratios of economic goods are permanently fluctuating. There is nothing constant and invariable in them. As Mises points out (1963, p. 210), actual market prices "are not facts in the sense in which a physicist calls the establishment of the weight of a quantity of copper a fact. They are historical events, expressive of what happened once at a definite instant and under definite circumstances."

Only a few market participants first perceive market changes. Moreover, different participants make different expectations about effects of those changes. "The more enterprising and brighter individuals take the lead; others follow later. Economists must never disregard in their reasoning the fact that the innate and acquired inequality of men differentiates their adjustment to the conditions of their environment" (Mises, 1963, p. 328). 
Each individual contributes to the formation of market prices by buying and selling. The impact of its contribution depends on the size of a market. If the market for particular good is small (or individual has sufficient economic power), then market participant is able to influence the market price. Such market participant is called "price-maker". If the market for particular good is broad (or individual has negligible economic power), then market participant cannot affect the market price. The market price appears to be just a datum to which market participant has to adjust his/her conduct. Such market participant is called "price-taker".

However, we cannot interchange valuation made by an individual and real market price. Valuation is a value judgment concerning with differences in value of various sets of goods. Each market participant attaches a higher value to the goods he receives than to the good he sacrifices. The market actions taken by market participations based on their valuations constitute market prices. The most importing thing is that "the exchange ratio, the price, is not the product of equality of valuation, but, on the contrary, the product of a discrepancy in valuation" (Mises, 1963, p. 331). In this context, we can consider market price as an economic counterpart of accounting concept of fair value. Then, fair value income can be denoted as the approximation of economic income. Fair value is a market-based value. Market prices always encompass the expectation of market participants about future course of demand for and supply of particular economic good. The future conditions are transformed to the current prices by discounting. Fair value income is future-oriented and its features are close to the characteristics of the Hicks' (1946) Income III concept.

\section{Evaluation of Fair Value Issues Occurring during Financial Crisis}

\subsection{Unrealised profits and possible erosion of capital}

Changes in fair value of entity's assets and liabilities recognised in income statement are holding gains and losses, which have not been realised as at the reporting date. As Abdel-Khalik (2008, p. 7) stresses changes in "fair values are only expectations the realization of which is conditional on many factors - primarily management decision to liquidate the position and market stability or volatility." Calling Mises remark on the inconstancy of prices, we should be aware when deciding whether to distribute or not such unrealised profits.

\section{Example 1: Distribution of Income}

An entity bought an asset measured at fair value through profit and loss for $100 €$. Market price of the asset at the reporting date is $110 €$. Next reporting period, the asset is sold for the price of $85 €$.

Net income for Period 1 is $10 €$ and can be paid out as a dividend (if commercial law allows such a distribution) despite the fact that this profit is unrealised. However, the market price in subsequent period has declined and in order to stop further losses, the asset is sold for price, which does not recover initial purchase costs. Net income for Period 2 is ( $25 €$ ). Therefore, the entity incurred total loss of $15 €$. From this point of view, the entity eroded its initial capital because of paying out cash dividends. 
Under historical costs model, the revaluation up to $110 €$ is not allowed as the prudence principles forbids entities to recognised revenues before they are realised. Consequently, Net income for Period 1 is zero and Net income for Period 2 is $(15 €)$. The total income is the same; however, its allocation between periods differs.

The Example 1 illustrates the possible risk of capital erosion stemming from distribution of unrealised profits. From my point of view, the function of accounting is not to hinder the users from distributing unearned profits. Financial reporting should only inform the users what can be distributed without erosion of capital. However, the decision whether to maintain the entity's capital is just up to the owners. It is a competence of the state authorities to set restrictions on the distributable income, but only if reasonable arguments for such restrictions exist (the protection of creditors, minority owners, etc.).

In my opinion, this argument against fair value is an odd one. The critics of FVA believe that under historical cost model or amortised cost model, which they consider the alternatives to the fair value model, the erosion of capital due to distribution of unrealised profits cannot happened. Historical cost accounting contains incentives to get up to "gains trading" or to securitize and sell assets. There is no economic difference between unrealised profit (holding gain), which has emerged due to the change in fair value and realised profit arisen by selling an asset at the selling price higher than purchase price, if the profit has been reinvested in another asset.

The discretionary in accounting numbers in historical cost model reaches a higher level than in the case of fair value measurement and this was one of major reasons for the implementation of fair value measurement in financial reporting. The return to historical costs would lead to old problems. Moreover, disadvantages of historical costs make things worse during crises (Laux and Leuz, 2009a).

Although the argumentation is provided in favour of fair value accounting as far as distribution of unrealised profits, it does not mean that everything is all right. The appeals for restrictions on distribution of unrealised profits may be considered relevant and justifiable for some purposes. The regulation of banks and other financial institution is on the top of the list. The banking regulation seeks to secure prudential behaviour of banks and thereby to curtail risks, to which economic subjects are exposed. One of the most important measures in this context is the minimum capital requirements set up e.g. by Basel Conventions. The calculation of some ratios (e.g. Tier 1) stems from accounting figures, although some amounts (e.g. unrealised profits recognised on mark-to-market basis) included in the accounting measure of capital may not be appropriate for the banking regulation. However, the calls for an exclusion of fair value out of financial statements cannot be accepted, because:

- financial statements objective is to provide information useful to present and/or potential investors and creditors and other users in making their economic decisions about scarce resources allocation;

- financial statements prepared in accordance with worldwide accepted accounting principles (such as IFRS and US GAAP) are oriented to meet general purposes informational needs of users, not the specific requirements of particular users $(e . g$. 
banking regulators); fair value is a relevant value attribute as confirmed by many studies $^{2}$ and information on fair values have to be kept with financial statements;

- regulators of financial institutions have power to require regulated companies to prepare additional figures and disclosures in order to refine the calculations of minimum capital;

- regulators can exclude inappropriate accounting figures from calculations and actually they do so;

- the responsibility to secure stability of financial system is a sole matter of bank regulators and cannot be passed on the accounting standards setters.

It could be recommended as additional prudential provision for the purpose of financial sector regulation that the distribution of unrealised profits by banks is not allowed. This provision could create a safety pillow hindering the erosion of capital and thus strengthening the stability of financial sector. However, this decision can be made only by legal authority (government and/or parliament) or by regulator if it has the competence for doing it.

\subsection{Reliability and relevance of fair value measurement}

The definition of fair value both in the US GAAP and in the IFRS presumes that an entity "is a going concern without any intention or need to liquidate, to curtail materially the scale of its operations or to undertake a transaction on adverse terms" (IAS 39.AG71). Consequently, fair value is delimited as a price agreed by a willing buyer and a willing seller in an arm's length transaction. Fair value is market-based measurement, which is not entity-specific.

Nevertheless, the entity always possesses advantages or disadvantages relative to others because there is impossible two similar entities in all aspects to exist. An entity's best estimate of fair value does not necessarily equal the "real" fair value. If the entity measures an asset or liability at fair value or in general if entity re-measures an asset or liability, it tends to take into account its perceived advantages or disadvantages relative to others marketplace participants. Such a practice can result in the deviation from requirements of financial reporting standards; however, this fully corresponds to the Mises' inferences regarding functioning of markets.

The low reliability of fair value measurement is the main issue esp. when market prices are rapidly falling and/or when markets suffer from lack of liquidity. The estimates of fair value may become distorted by forced sales or fire sales (compare with Bernanke's speech). However, the definition of fair value does not work with the force sale, but with orderly transaction. The issue, that should be resolved, is whether more reliable and relevant information is provided by measurement based on actual market data (Level 2 of the Hierarchy) or by using specific model (Level 3 of the Hierarchy). In case that observed prices of similar assets (inputs for Level 2 measurements) are results of a disturbed transaction, entities are obliged to adjust observed market prices in order to take into account specific attributes of asset being measured. Relatively strict requirements of accounting standards restrict the scope for management manipulation with the estimates significantly.

2 See Barth and Landsman (2010, p. 404) for the detailed overview of mentioned studies. 
For the enhancement of usefulness of financial statement, I would recommend to split up income statement to several subgroups. Income from operating activities should be divided into a realised and unrealised part with the separate disclosure of fair value changes (Abdel-Khalik, 2008, suggests another interesting solution). Fair value changes are an important indicator of an entity's ability to foresee future development and to react on actual market conditions. Therefore, they should be reported and they should be reported separately. Even if market prices are rapidly increasing or decreasing, fair values are more accurate and comparable across different entities. The current critique of fair value in terms of its low reliability and relevancy is not well founded and it is only purpose-built cry of those who previously profited on the increasing prices, but who must cope with bigger losses now. ${ }^{3}$ The fall in prices during credit crunch was a real economic phenomena and financial reporting should reflect the economic course to provide the users with useful information. Moreover, all unrealised gains and losses should be a subject of detailed explanation by management of entity. If managers failed to explain those gains and losses appropriately, the users would gain an indicator that something important happened.

\subsection{Suboptimal behaviour}

The most serious objection to fair value accounting, which is based on macroeconomic grounds, is that FVA is strongly procyclical. The procyclicality should have occurred in two ways. Firstly, banks were unable to find the clients wanting new credit financing, as the market with new loans had almost frozen. The private consumption slumped and due to economic contraction, the market prices of financial instruments began to fall. As a consequence, banks and other financial institutions were required to impair the "infected" assets. In addition, the bank were forced to sell their assets in order to meet minimum capital requirements, which leads to further impairments down to prices which were supposed to be unrealistically low. Mark-to-market accounting based on forced sales deepened and amplified thus the "real" economic crisis. This argument against FVA is an important one and needs further investigation.

Principally, extreme fair value write-downs could not be excluded as a cause of financial and economic crisis. For this reason, it is necessary to distinguish between real (natural) and artificial (amplified) procyclicality. The credit crunch and the impossibility to raise new loans because of saturated demand is surely a natural cause/ consequence of economic downturn and cannot be attributed to accounting. The only source of potential artificial procyclicality remains on the impairment charges of assets and liabilities treated under fair value model combined with forced assets sales. It is a quite difficult to find arguments whether reasons behind this process are natural or artificially elicited by inappropriate accounting rules.

The focus should be aimed at assets, which are subject of remeasurement to fair value or assets for which impairment test refers to fair value. We can presumably believe that substantial differences among various financial institutions exist. According to the US Securities and Exchange Commission Report (SEC, 2008, p. 47) the percentage of assets measured at fair value ranged from $14 \%$ by credit institutions to $50 \%$ by brokers

The biggest critique comes unsurprisingly from the managers of financial institutions. 
and even up to $71 \%$ by insurance companies. The share of fair value assets amounts $31 \%$ for the bank industry. Moreover, commercial banks were influenced in a lesser extent as the major part of their balance sheets is comprised of loans and assets held-tomaturity, both of which are measured at their amortised costs. This corresponds with the findings of Laux and Leuz (2009b, pp. 9-10) about insignificant share of traded securities on the balance sheets of commercial banks (under 15\%). Contrary to the general beliefs, the studies provide evidence that link between impairment based on fair value and forced sales, which causes another drop-down of prices with necessity to incur additional impairment losses was very loose in the banking sector. Commercial banks unlikely were caught in the spiral "fall in market prices $=>$ impairment losses $=>$ forced sales of affected assets $=>$ further fall in market prices $=>$ further impairment losses" and the procyclical character of FVA can be denied at least for commercial banks. The problems of commercial banks, which caused the economic slowdown, were not a consequence of procyclical nature of FVA, but they have rather real economic roots (e.g. origination of mortgages to people with low credibility and ability to repay the loan).

Another fallacy, which is presented by the opponents of FVA, is that the forced sales of impaired assets are an inevitable consequence of unsuitable accounting standards. In order to meet regulative requirements on minimum capital, banks are allegedly forced to sell their assets in order to generate cash, restructure their assets and to fit the minimum capital requirements. This is not the truth obviously. The sale of assets is not the only way to sustain Basel Convention requirements. Alternatively, it is possible to raise new share capital without necessity to sell assets below their "real" value. Moreover, it is disputable whether the sales of assets, which happened, were actually "forced" (to meet capital requirements) or whether banks and other financial institutions made the sales voluntarily. Stop-loss sales on behalf of clients to minimise their losses may be one of reasons for sales, which did not have any association with recognised impairment losses. Short sales speculating on further future drop-downs in market prices can be another motivation, which turned into the abnormal excess of supply over demand on the market with financial instruments during the crisis. Market speculation on future development of prices is an inherent feature of market economy. These are real phenomena, possibly influencing the economy in a procyclical manner. (Un)fortunately, financial reporting does not possess any tool for hindering the market participants from such behaviour and in this context fair value accounting plays no role in the recent turmoil.

Disregarding whether the sales of assets were forced or not, it has to be pointed out that no accounting measurement model is immune to decline in market prices. The prudence (conservatism) as traditional accounting principle requests that assets and revenues are not overstated and liabilities or expenses are not understated. Therefore, most assets are traditionally measured with the reference to "lower of cost or market method'. In case of abandoning fair value measurement and returning back to historical costs, the entities will be still required to recognise impairment losses if carrying amounts of assets exceed their recoverable amounts. Consequently, banks and other financial institutions may be forced to sell the assets to meet capital requirement under historical cost regime, too.

The only weakness of FVA in comparison with historical cost model is that it 
allows revaluation up to current market price, which is not perceived as prudent. If a market price for a given asset goes down below its original purchase costs, the difference between fair value (up to which the assets was revaluated in the last financial statements) and current fair value is higher than in historical costs model (see Example 1). Therefore, the impairment losses under fair value model can be of a greater extent than under historical costs. The complications with FVA arise because financial institutions carry out their operation on the very edge of the Tier 1 and other requirements with low or even none security reserve. The distribution of unrealised profits erodes capital during good times. In bad times, the previous capital erosion leads to calls for either to sell out the affected assets or to pour into new share capital. There are two possible solutions to this issue. Firstly, bank regulators can impose the ban on distribution of unrealised profits (which is, however, politically unpopular measure). Secondly, additional detailed disclosure on components of net income with the focus on distinction between realised and unrealised part can be required by the standard setters.

Regardless fair value accounting is procyclical or not, the procyclicality cannot be a justification for the rejection of fair value as a measurement basis. If fair value provides relevant information for decision-making of individuals, their interests cannot be given up in the favour of undefined aggregate "entity". The problems, to which financial institutions faced during the credit crunch, were the real economic issues with the roots in excessive monetary expansion of central banks and unaccountable behaviour of financial institution in times of monetary expansion. Any consequent difficulties (e.g. the necessity to raise capital in order to meet minimal capital requirements) shall not be solved by ignoring the reality (i.e. by the dismissing of fair value measurement), but on the regulatory level setting the basic conditions for doing the business. The redefinition of capital with the respect to fair value measurement is needed (Heaton et al., 2009).

Moreover, fair value measurement is a useful indicator of an entity's ability to foresee the future price movements. Recent financial crunch has many losers, but also some winners. Those who had seen the seeds of the crisis in advance, have undertaken respective measures, and have changed their assets portfolios won. They not only survived the crisis, they became even stronger than they had been before the start of credit crunch. Fair value accounting is neutral in respect of excessive prudence. If fair value measurement is implemented properly, it portraits the reality as it is. Under unfavourable market development, fair value accounting enables the users to distinguish the winners from the losers. The latter ones cannot manage their earnings using the hidden reserves acquired in good times.

If refers to current market situation, fair value measurement is a tool useful to broad group of users in their decision-making. Fair value measurements constitute a relevant source of information for evaluation of financial position and performance. If market prices suffer from economic downturn, (fair value) accounting just portrays the reality. The crucial factor influencing amounts reported in financial statements is the real health of an entity and the nature of transactions, which the entity undertook in the past. Those banks and institutions, which did not engage in speculative and other 
harmful trades extensively, they have survived turmoil without any serious impact. ${ }^{4}$

Similar results presents the study by Khan (2010) focusing on the economic consequences of the relaxation of FVA and impairment rules by SEC/FASB and IASB for the banking industry as the reaction to the negative development in financial markets. The study shows, that "the magnitude of stock price reactions to the relaxation of FVA and impairment rules was positively related to (i) banks being less than 'well-capitalized'; (ii) banks with more illiquid assets; and (iii) banks' likelihood of being subject to other-than-temporary impairments related to the 2008-09 financial meltdown" (Khan, 2010, p. 27). It means that fair value is a measurement attribute with negative consequences only for those entities, which are not at healthy financial condition. This empirical evidence supports the assertion that fair value accounting only displays real economic problems and shows in a bad light only those entities, which suffers from real economic troubles.

\section{Conclusions}

The paper analysed the economic features of fair value measurement basis. The economic concept of income and the general theory of measurement were the foundations for the evaluation of the role of fair value accounting in the recent financial crunch. Fair value is the measurement concept that possesses the ability to represent truly and fairly the economic reality in the way, which is found useful by the users of financial statements. From the economic point of view, only current and market-based value is relevant for the decision-making of the users of financial statements. Conceptually, fair value is superior to the other measurement bases. In order to be a useful measurement basis, fair value must refer to market prices - directly or at least indirectly.

However, current definition of fair value is somehow unclear. There are some questions, which need a deeper explanation, e.g. should fair value be an exit price, an entry price, a mid price, a neutral price? Moreover, I can see a conceptual contradiction between requirements on the fair value determination and the approach to the classification with particular element of the balance sheet. Fair value should be independent on the entity, but the classification of an element often depends on the purpose why the entity acquired the element. The classification influences the subsequent measurement of the element. The discretion in the classification of balance sheet elements can lead to the outcome that the same element is treated differently across entities (some entities may measure the element at its fair value, others at its historical costs, etc.). The comparability and relevance of financial statements are then reduced. The definition of fair value and principles of its usage are crucial factors in achieving true and fair view of economic reality in financial statements.

4 Czech banking sector can serve as a very good support for this assertion. Czech banks are very conservative; their deposits exceed credits by $30 \%$, which is the highest value in the EU. Together with the fact that Czech banks prefer conservative investment strategies with a low share of stock market investments it results only in a slight decline in profits in year 2008. In 2009 and 2010, some Czech banks have reported the highest profits in their history, even higher than in pre-crisis period. For further information, see Holman (2010). 
The last issue, which requires the attention, concerns the determination of fair value in the concrete situations. In this connection, it is necessary to decide whether only one fair value for the element exists or if it is possible that several fair values can exist for the particular item. This problem arises chiefly when the evidence of market prices is missing. The guidance on fair value in financial reporting standards sets the duty to derive fair value under condition of hypothetical arm's length transaction. However, even if the responsible person does his/her best, it is impossible to omit own perceptions of the market situation (see Mises remark on this topic). Thereby, financial reporting is caught in a little schizophrenic situation. According to standards, fair value information is not entity-specific and the fair value across entities should be the same. In reality, fair value encompasses entities' opinions, observations and understanding of the market situation. Consequently, users can get different fair values for the same asset/liabilitity. If the variations are significant, the comparability and relevance of financial statements are then reduced again. The correctness in pursuing the guidance on fair value measurement constitutes another crucial factor in achieving true and fair view of economic reality in financial statements.

Despite some disadvantages mentioned above, fair value remains the best available basis for measurement certain elements of financial statements. The critique of fair value accounting, which emerged after as reaction on financial crunch, is in some extent legitimate. However, the opponents do not offer any functional alternative. Such alternative have to both mitigate the negative impacts of fair value and solve the problems of historical costs for which the traditional measurement model was abandoned in favour of fair value. We should have in mind that each alternative to fair value is a measurement basis, which is "unfair", actually.

Recent negative economic development has brought new insights into the functioning of markets (and esp. markets with financial instruments). The paper tried to outline some reasons whether fair value accounting should or should not be blamed for the mentioned downturn. There were presented both theoretical approaches from economic and accounting theories and some empirical evidence as well. However, I believe that the main argument in favour of further utilisation of fair value can be offered by common sense.

The starting point is the finding that non-financial companies were also severely hit in recent years and they recorded big losses (and many of them became bankrupted). This happened despite the fact that fair value is not significantly used by non-financial companies (empirical evidence on this topic is provided by Bachert and Kajüter, 2010, p. 16). Therefore, we should distinguish carefully between economic and financial crises and their impacts on financial and non-financial companies. It is believed that the financial crisis hitting banks and other financial institutions occurred firstly; and non-financial companies were not influenced by the financial crunch. In the second phase, economic slowdown hit almost all companies regardless on industry in which they operate.

As fair value measurement is not applied by non-financial companies significantly, we do not have any logical argument supporting the opinions that fair value is the cause of economic crisis. Although banking sector and capital markets suffered from some problems, the non-financial companies did not lose the access to financing if they wanted to raise new resources for their activities. The problem was rooted in an investment part of banks' balance sheets. It turned out that the asset prices were 
overstated. As a reaction to the negative development of the real economy indicators (esp. in the U.S.A.) the process of stock-market prices correction started. Therefore, the time consequence is a little bit contrary, as it is generally assumed. At first, some problems in real economy (esp. in real estate market) appeared. These fluctuations were rapidly reflected by financial markets and the stock-prices fell down. Simultaneously, the economic crisis burned in the full strength.

We can suspect many reasons, which could have caused the crisis. Based on the economic symptoms of the crisis, which tightly correspond with the Austrian economic theory of economic cycle, huge monetary expansion can be assumed as the main driver of the economic crisis. The excess of money supply led to the overstatement of market prices for financial instruments. Then, the focus shifted to real estate and other real economy markets. High prices did not reflect the fundamental factors and were therefore not attainable. The inevitable had to happen. The final drop in stock-market prices was unprecedented, but unavoidable because of long-term market disequilibrium. The rapid occurrence of financial derivatives and asset securitisation combined with their weak regulation could be the second factor causing the crisis. However, this type of research is outside the scope of the paper (more detailed discussion can be found in Barth and Landsman, 2010, pp. 407-415).

To conclude, fair value measurement should not be blamed for the economic downturn and financial crunch; the root of problems is lying outside this part of financial reporting. On the contrary, the recent financial crisis helps us to reveal that fair value can be an important tool to distinguish healthy companies from unhealthy ones. We may even suppose that fair value measurement is a very useful in the process of scarce resources allocation. This assertion is in the line with the empirical findings and conclusions of Khan (2010, p. 28) according to which "FVA merely accelerates the price and resource allocation adjustment processes resulting in a relatively speedy return to financial stability". Fair value as a market price always encompasses the expectation of market participants about future course of demand for and supply of particular economic good. Thus, market prices, of which fair value is the most powerful representative, play an important role for smooth functioning of market economy and all efforts calling for its suspension are odd.

They are of course some limitations to FVA usage. Although fair value measurement is not directly assignable to the financial crisis, many issues need to be resolved. The most problematic is the measurement of financial instruments, which qualify no better than for the Level 3 of fair value hierarchy. The valuation of Level 3 positions is based on models with unobservable market inputs. The resulting fair values are subjective and difficult/ impossible to verify by the users outside the entity. During the financial crisis, markets of certain financial instruments have become illiquid, and as a result, fair values posses less reliability than usual.

There are two possible, but not ideal solutions, how to enhance relevance of accounting information. Firstly, one might suggest excluding financial instruments, which can be measured at fair value only with the reference to unobservable market inputs, out of scope of fair value accounting. However, this solution is doubtful in times of unusual market movements such last financial crisis. It can happen that an active market can cease to exist for some instruments, which were previously measured at fair value with reference to directly ascertainable market price. The change from 
fair value measurement basis to another basis, whichever it would be, can violate the perception of comparability of accounting information in the eyes of investors. Secondly, the instruments, for which neither Level 1, nor Level 2 are available, may be measured at zero value to express that they could not be traded at markets. The automatic impairment to zero would be also an important issue in turbulent times, when the markets are not functioning at all. Therefore, we may wish to retain current system with all its disadvantages (low reliability of and higher possible discretionary in measurement) as it represents a model with balanced benefits and costs.

Whichever solution will be followed, the limits of financial reporting as information source shall not be ignored. When implementing financial reporting standards, all interested parties (standard setters, preparers and users) should be aware that the measurement in accounting is mostly surrogated by its nature. We are not able to define a solid set of principles for the measurement, which would ensure perfect (absolute) portrait of economic reality in the financial statements. The measurement in financial reporting is always conforming to the present-day economic paradigm and is, therefore, subject to a possible change. However, the fluctuations of economic performance within a single paradigm (i.e. recent credit crunch) cannot be a reason for the abolishing of the principles in force (i.e. fair value accounting).

\section{References}

Abdel-Khalik, R. A. (2008), "The Case against Fair Value Accounting." University of Illinois, [on-line], www.aislab.aueb.gr/accfin/DownLoads/seminars/ATT00007.pdf.

American Bankers Association (2008), Letter to SEC on Fair Value and Other Accounting Standards. Washington: September 23, 2008.

Andre, P., Cazavan-Jeny, A., Dick, W., Richard, C., Walton, P. (2009), "Fair Value Accounting and the Banking Crisis in 2008: Shooting the Messenger." Accounting in Europe, Vol. 6, No. 1, pp. 3-24.

Australian Accounting Research Foundation (1997), Responses to Invitation to Comment: ED 83. Melbourne: AARF, 1997.

Bachert, K., Kajüter, P. (2010), "Fair Value Accounting and Financial Analysts' Forecast Accuracy: Empirical Evidence from Seven European Countries." Istanbul, 33rd Annual Congress of the European Accounting Association, 18. 5. 2010 - 21. 5. 2010.

Barlev, B., Haddad, J. R. (2003), "Fair Value Accounting and the Management of the Firm." Critical Perspectives on Accounting, Vol. 14, No. 4, pp. 383-415.

Barth, M. E. - Landsman, W. R. (2010), "How did Financial Reporting Contribute to the Financial Crisis?" European Accounting Review, Vol. 19, No. 3, pp. 399-423.

Barth, M. E. (2006), "Standard-Setters, Measurement Issues, and the Relevance of Research." London: ICAEW Information for Better Markets Conference, December 18-19, 2006, [on-line], www.icaew.co.uk/index.cfm?route $=143927$.

Beatty, A., Chamberlain, S., Magliolo, J. (1996), "An Empirical Analysis of the Economic Implications of Fair Value Accounting for Investment Securities." Journal of Accounting and Economics, Vol. 22, No. 1, pp. 43-77.

Bloomfield, R. J., Nelson, M. W., Smith, S. D. (2006), "Feedback Loops, Fair Value Accounting and Correlated Investments." Review of Accounting Studies, Vol. 11, No. 2-3, pp. 377-416.

Chambers, R. J. (1966), Accounting, Evaluation and Economic Behavior. Houston: Scholars Book (reprinted 1974), ISBN 0-914348-15-9. 
Escaffre, L., Foulquier, P., Touron, P. (2008), "The Fair Value Controversy: Ignoring the Real Issue." Lille - Nice, November 25, 2008, [on-line], http://www.edhec-risk.com/features/ RISKArticle.2008-11-25.0644/attachments/EDHEC\%20Position\%20Paper\%20Fair\%20Value.pdf.

Edwards, E. O., Bell, P. W. (1961), The Theory and Measurement of Business Income. Berkeley: University of California Press (reprinted 1973), ISBN 0-520-00376-4.

Financial Times (2008a), "An Unforgiving Eye: Bankers Cry foul over Fair Value Accounting Rules." March 13, 2008, [on-line], http://us.ft.com/ftgateway/superpage. ft?news_id=fto031320081631003695.

Financial Times (2008b), "Banks Want to Shoot the Messenger over Fair Value Rules." Financial Times, October 2, 2008.

Fisher, I. (1906), The Nature of Capital and Income. New York: The Macmillan Co.

Fisher, I. (1930), The Theory of Interest. New York: The Macmillan Co.

Hayek, F. A. (1967), "The Result of Human Action But Not of Human Design," in Studies in Philosophy, Politics and Economics. Chicago: University of Chicago Press, pp. 96-105.

Heaton, J., Lucas, D., McDonald, R. (2009), "Is Mark-to-Market Accounting Destabilizing? Analysis and Implications for Policy." Carnegie Rochester Conference on Public Policy, April 17-18, 2009, [on-line], http://www.carnegie-rochester.rochester.edu/april09-pdfs/HeatonLucasMcDonald.pdf.

Herbohn, K. (2006), "Accounting for SGARAs: A Stock Take of Accounting Practice before Compliance with AASB 141 "Agriculture". Australian Accounting Review, Vol. 16, No. 2, pp. 63-77.

Hicks, J. R. (1946), Value and Capital: An Inquiry into Some Fundamental Principles of Economic Theory. Oxford: Clarendon Press.

Hitz, J-M. (2006), "The Decision Usefulness of Fair Value Accounting - A Theoretical Perspective." Cologne Working Papers on Banking, Corporate Finance, Accounting and Taxation, [on-line], http://www.wiso.uni-koeln.de/workingpapers/bcfat/index.html.

Holman, R. (2010), "The Czech Financial Sector Remains Stable Even at a Time of Recession." Czech National Bank, [on-line], http://www.cnb.cz/en/public/media_service/interviews/cl_100520.html.

Khan, U. (2010), "The Economic Consequences of Relaxing Fair Value Accounting and Impairment Rules on Banks during the Financial Crisis of 2008-2009." Istanbul, 33rd Annual Congress of the European Accounting Association, 18. 5. 2010 - 21. 5. 2010.

Kuhn, T. S. (1962), The Structure of Scientific Revolutions. Chicago: University of Chicago Press.

Laux, C., Leuz, C. (2009a), "The Crisis of Fair Value Accounting: Making Sense of the Recent Debate." University of Chicago: Initiative on Global Markets, Working Paper No. 33, [on-line], http://ssrn.com/abstract=1392645.

Laux, C., Leuz, C. (2009b), "Did Fair-Value Accounting Contribute to the Financial Crisis?" National Bureau of Economic Research: Working Paper No. 15515, [on-line], http://www.nber.org/papers/ w15515.pdf.

MacNeal, K. (1939), Truth in Accounting. Houston, Scholars Books (reprinted 1979), ISBN 0-914348-04-3.

Magnan, M. (2009), "Fair Value Accounting and the Financial Crisis: Messenger or Contributor?" CIRANO: Scientific Series, Montreal, 2009.

Mises, L. (1966), Human Action: A Treatise on Economics. Chicago: Contemporary Books.

Nobes, C. (2001), "Asset Measurement Bases in UK and IASC Standards." London: Certified Accountants Educational Trust, 2001.

O‘Grady, S. (2008), "Banks Are Overstating Losses, Says King." Independent, May 1, 2008, [on-line], http://www.independent.co.uk/news/business/news/banks-are-overstating-losses-saysking-818847.html.

Penman, S. (2006), "Financial Reporting Quality: Is Fair Value a Plus or a Minus?" London: ICAEW Information for Better Markets Conference, December 18-19, 2006, [on-line], http://www.icaew. co.uk/index.cfm?route $=143928$. 
Plantin, G., Sarpa, H., Shin, H. S. (2005), "Marking-to-Market: Panacea or Pandora's Box?" Chicago, [on-line], http://faculty.chicagobooth.edu/finance/papers/mtm.pdf.

Rappeport, A. (2008), "ABA Levels New Blast at Fair Value." CFO.com, 24 September, 2008, [on-line], http://www.cfo.com/article.cfm/12287228/c_12304033?f=home_todayinfinance.

Richard, J. (2002), "The Concept of Fair Value in German and French Accounting Regulations 1673-1914." Copenhagen: European Accounting Association Annual Congress, April 2002.

Rummell, N. (2008), "Fair-value Rules Get More Blame for Crunch." Financial Week, 24 March, 2008, [on-line], http://www.financialweek.com/apps/pbcs.dll/article?AID=/20080324/ REG/854569832.

Ryan, S. G. (2008), "Accounting in and for the Subprime Crisis." The Accounting Review, Vol. 83, No. 6, pp. 1605-1638.

U.S. Securities and Exchange Commission (2008), "Report and Recommendations Pursuant to Section 133 of the Emergency Economic Stabilization Act of 2008: Study on Mark-To-Market Accounting."

Veron, N. (2008), "Fair Value Accounting Is the Wrong Scapegoat for this Crisis." Bruegel Policy Contribution, May 2008, [on-line], http://aei.pitt.edu/8378/01/PC200803.pdf.

Wallison, P. J. (2008), "Fair Value Accounting: A Critique." American Enterprise Institute for Public Policy Research, AEI Outlook Series, July 2008, [on-line], http://www.aei.org/ docLib/20080728_23336JulyFSOg.pdf.

Wallison, P. J. (2009), "Fixing Fair Value Accounting." Paris, OECD Accrual Accounting Symposium, 2 March 2009, [on-line], www.oecd.org/dataoecd/1/22/42416969.pdf. 